\title{
Attitudinal and Revenue Effects on Non-Industrial Private Forest Owners' Willingness-to- Harvest Timber and Woody Biomass
}

\author{
Abstract \\ In the U.S., prospects for greater use of woody biomass as a source of renewable energy are \\ contingent on supply from privately-owned forestlands. This study surveyed non-industrial \\ private forest (NIPF) owners in the states of Michigan, Minnesota and Wisconsin to elicit their \\ willingness-to-harvest (WTH) timber and woody biomass. Results consistently showed that \\ higher revenues, associated with higher prices, and attitudes supporting harvesting of woody \\ biomass were associated with greater WTH levels. Intentions of not conducting a commercial \\ harvest in the future were a strong predictor of WTH. Average effects differed by state. Else \\ constant, Minnesota respondents reported higher WTH and showed greater responsiveness to \\ timber and biomass revenue changes compared to their counterparts in Michigan and Wisconsin. \\ Absentee ownerships, different opinions regarding environmental impacts of biomass harvesting, \\ divergent ownership objectives, past harvest experiences and future harvest plans, and \\ environmental organization membership helped explain different WTH levels across states. \\ Marginal probability analyses suggest revenues from woody biomass, as compared to timber, \\ had much lesser influence on potential supply of woody biomass from NIPFs. Differences in \\ WTH estimates between states suggest that strategies to increase availability of woody biomass \\ should be crafted to each state's conditions and emphasize alternatives to increase timber \\ revenues.
}

Keywords: Woody biomass, bioenergy, social availability, non-industrial private forest owners, US Great Lake States

(C) 2015. This manuscript version is made available under the Elsevier user license http://www.elsevier.com/open-access/userlicense/1.0/ 


\section{Introduction}

Woody biomass may be defined as "the trees and woody plants, including limbs, tops, needles, leaves, and other woody parts, grown in a forest, woodland, or rangeland environment, that are the by-products of forest management" (U.S. Forest Service, 2008). The utilization of woody biomass for energy creates a market for traditionally unusable materials, supports associated job opportunities and can reduce forest fire hazards (Hall, 1997; Aguilar and Garrett, 2009; U.S. Forest Service, 2008; Department of Energy, 2010). Energy derived from woody biomass and other wood materials already account for $22 \%$ of the renewable energy consumed in the U.S. and its use in recent years has grown significantly in co-firing systems for power generation (to replace coal) and the residential sector (Aguilar and Mabee, 2014; Energy Information Administration, 2014). Given its physical availability, and if used efficiently, woody biomass could be part of a comprehensive approach to decrease carbon emissions associated with energy generation and reduce dependence on fossil fuels (Bartuska, 2010). The environmental and economic benefits associated with the utilization of woody biomass as a renewable, reliable and domestically produced fuel and its potential to displace fossil fuels has been recognized nationally (EPA, 2010; P.L. 110-140, Aguilar and Saunders 2010).

Forests cover about $33 \%$ or 303.9 million hectares of land in the U.S and nearly $40 \%$ of these forestlands are owned by non-industrial private forest (NIPF) owners (Butler, 2008; Smith et al., 2009). U.S. NIPF owners represent the nation's largest ownership group and, thus, constitutes one of the most important sources of forest resources (Butler, 2008). In the U.S. Great Lakes States of Michigan, Minnesota and Wisconsin the predominance of private ownership is notably pronounced at 58\% of the 21.1 million hectares of forests in the region (Smith et al., 2009). 
NIPFs extend over 10 million hectares which equates to approximately $83 \%$ of all private forestlands in the Great Lakes region (Butler, 2008). This translates to NIPF ownership representing 48\% of forestlands in Michigan, 36\% in Minnesota and 59\% in Wisconsin (Smith et al., 2009).

Bio-physical estimates on woody biomass have been derived for the Great Lakes region (e.g. U.S. Department of Energy, 2011; Goerndt et al., 2012) demonstrating the capacity of Michigan, Minnesota and Wisconsin to create a viable wood-based bioenergy market. But the availability and ultimate supply of woody biomass can be constrained by social factors. Specifically, Butler et al. (2010) stress the importance of social availability of woody biomass as a concept denoting how social factors will determine actual versus potential woody biomass supply. Given the extent of NIPFs in a region identified for its potential to use woody biomass for renewable energy generation the decisions NIPF owners will be instrumental in determining the social availability of woody biomass (Butler et al., 2010). The aim of this study was to examine and compare regional differences associated with NIPF owners' willingness-to-harvest (WTH) timber and woody biomass in the U.S. Great Lakes States of Michigan, Minnesota and Wisconsin. This region was selected due to its reported potentially available woody biomass. Biophysical availability was estimated to be 37 million dry tons per year according to Becker et al. 2009). Social availability has been explored in Minnesota, Wisconsin and Michigan (Becker et al., 2013; Aguilar et al. 2014), however, no study has examined state-level differences in NIPF owners' WTH nor simultaneously evaluated how supply is affected by commercial timber and woody biomass prices and corresponding revenue levels. Specific objectives were to identify and compare factors influencing NIPF owners' WTH timber and woody biomass and to examine and 
contrast NIPF owners' WTH responsiveness to timber and biomass revenue changes in each state.

\section{Literature Review}

The literature to-date has discussed at length the impacts of numerous conditions on landowners' decisions to engage in forest harvest (Amacher et al., 2003; Kurtz and Lewis, 1981; Tonisson, 2012; Vokoun et al., 2005; Young and Reichenbach, 1987). Specific factors found to affect landowners' timber harvesting decisions include stumpage price, parcel size, technical assistance, ownership objectives, membership in an organization and demographics like age, income and education (Amacher et al., 2003; Beach et al. 2005; Binkley, 1981; Butler 2007; Kurtz and Lewis, 1981; Vokoun et al., 2005; Young and Reichenbach, 1987). However, their reported magnitude and statistical significance on NIPF owners' harvest preferences have not been consistent across studies (Beach et al. 2005; Gregory et al., 2003). For instance, timber price was found to significantly affect NIPF owners' harvesting behavior in several studies completed in New Hampshire and the Southeastern U.S. region (Binkley, 1981; Boyd, 1984; Newman and Wear, 1993; Pattanayak et al., 2003). But other studies conducted with NIFP owners in Virginia and North Carolina found no statistically discernable timber price effects (Conway et al., 2000; Prestemon and Wear, 2000). Regarding ownership size, Binkley (1981), Conway et al. (2000), and Bolkesjo and Baardsen (2002) reported a direct association between parcel size and NIPF owners' harvest behavior after examining NIPF forests in New Hampshire, Central Virginia, and Norway. However, no such significant impact was found in Conway's (2000) study conducted in Southwest Virginia. According to Beach et al. (2005), who reviewed 18 empirical timber harvest studies, some of the reasons for the apparent inconsistency in 
reported effects might be associated to heterogeneous regions and differences in data collection, data type and quality and analytical methods.

Recent studies have also explored factors influencing stated preferences toward woody biomass harvesting among NIPF owners. Main findings have highlighted the role of biomass prices and demographic profiles on potential supplies. Becker et al. (2010) found that biomass price positively influenced forest owners' likelihood of harvesting biomass in Minnesota. Education positively influenced decisions to harvest woody biomass in the southern U.S., Minnesota and Missouri (Aguilar et al., 2014a; Becker et al., 2010; Gruchy et al., 2011; Joshi and Mehmood, 2011). Becker et al. (2010) reported significantly lower WTH woody biomass levels among absentee owners (i.e. those who did not reside on their woodlands) and those who did not believe its harvesting could improve U.S. energy independence. As it has been the case with WTH timber, heterogeneous results associated with ownership factors impacting NIPF owners' WTH woody biomass are reported. Owners' demographic characteristics such as age influence ownership objectives since older landowners are more likely to transfer or bequeath their forestland in the near future and would likely be less interested in harvesting timber and/or biomass (Butler and Leatherberry, 2004). Accordingly, older landowners have been found to be less likely to engage in commercial harvesting (Aguilar et al., 2014a; Becker et al., 2010; Gruchy et al., 2011; Joshi and Mehmood, 2011). However, a study conducted in Mississippi (Joshi et al., 2013) found that older NIPF owners were more likely to supply woody biomass as compared with younger landowners. Another example relates to the correlation of ownership sizes and WTH woody biomass. NIPF owners' stated WTH woody biomass for bioenergy in Arkansas, Florida and Virginia revealed similar findings with timber studies where an increase in forest 
ownership was positively associated with willingness to supply biomass (Joshi and Mehmood, 2011). However, a study of NIPF owners in Mississippi found that an increase in ownership size was inversely associated with WTH woody biomass (Gruchy et al., 2011). The effect of acreage on WTH, thus, is an important factor influencing NIPF owners' harvesting choices although the direction of its effect may not be certain.

This study contributes to the existing literature in three particular aspects. First, it aims to shed light on factors behind heterogeneous NIPF owners' WTH timber and woody biomass preferences between states in the selected study region. The degree of inconsistency in model estimates captures intrinsic regional differences, however, some of the apparent inconsistency may be associated to different research methods. This study examined differences in WTH and effects of explanatory variables across regions while using the same research methods including the same questionnaires, sampling technique, data collection methods, and analytical tools. To our knowledge, few studies have been conducted to explicitly examine regional differences associated with NIPF owners' WTH and none has simultaneously controlled for timber and biomass harvest effects. Second, the examination of NIPF owners' WTH woody biomass was elicited based on both woody biomass and timber revenues. A woody biomass harvest must be done in conjunction with higher-value products (e.g. timber and pulpwood) in order to be economically feasible (Aguilar et al., 2014a; Hubbard et al., 2007; Saunders et al., 2012), but as pointed out by Aguilar et al. (2014a), the published literature has come short in evaluating the social availability of woody biomass by not considering timber prices explicitly when estimating NIPF owners' WTH biomass. Third, this study contributes to the exploration of responsiveness to price and corresponding revenue per hectare changes. The literature has examined the impacts of 
timber and biomass prices on NIPF owners' WTH separately and often on an absolute basis instead of estimating elasticities to percent revenue changes. By doing so, this research discerns the impacts associated to timber and biomass price and corresponding revenues in the same units which is important given the significant price disparities between them.

\section{Theoretical Framework}

This study modeled NIPF owners' decisions as a utility maximizing choice determined by NIPF owner-specific attributes, land attributes and factors external to both owner and land, more specifically, market revenues for timber and woody biomass. Hence, utility derived from forest harvesting was modeled as: $U_{i}=f(\mathrm{~L}, \mathrm{LO}, \mathrm{E})+\varepsilon$; where $U_{i}$ is the utility received by the $i$ th NIPF owner from harvesting (or not), $\mathrm{L}$ is a vector of land attributes, LO is representative of NIPF owner attributes, E stands for external factors and $\varepsilon$ is a random error term.

In order to assess the utility associated with NIPF owners' choice to harvest their woodlands, a binary logit model was used. The latent variable $y^{*}$ is unobserved but related to the observed independent variables by the equation: $y_{i}^{*}=\mathrm{x}_{i} \beta+\varepsilon_{i}$ where $y^{*}$ is the latent unobserved utility derived by the $i$ th NIPF owner from a hypothetical harvesting choice, $\mathrm{x}_{i} \beta$ stands for a corresponding vector of explanatory variables (L, LO and E) and coefficients and $\varepsilon$ is the random error. The relationship between the latent $y^{*}$ and observed $y$, representing WTH is:

$$
y_{i}=\left\{\begin{array}{l}
1 \text { if } y_{i}^{*}>0 \\
0 \text { if } y_{i}^{*} \leq 0
\end{array}\right.
$$


Consequently, positive values of $y^{*}$ (where $U_{i}>0$ ) translate to an observed response where $y=$ 1 means an NIPF owner is willing to harvest her land while negative or zero values of $y^{*}$ would be observed as $y=0$ and represent unwillingness to harvest.

\section{Methods}

\subsection{Survey instrument and data collection}

Questionnaires for the study area including the Great Lakes states of Michigan, Minnesota and Wisconsin were developed with the survey instrument by Daniel (2012) used as an initial template. This instrument was designed to collect information on NIPF owners' views towards the harvesting of woody biomass for bioenergy, potential constraints to supply, as well as price preferences for carrying out a harvest. Based on published reports for market prices, forest resource inventories, reviews conducted by each state's Department of Natural Resources (DNR) and forestry experts from local land-grant universities a revised survey instrument was pre-tested among a sample of forest owners from the study area prior to distribution among NIPF owners.

The final survey instrument was composed of five sections. The first section included questions that collected information on NIPF owners' forest parcel sizes, years of ownership, forest management experience, future management plans, harvesting intentions regardless of price, road accessibility and whether respondents were residential or absentee owners (i.e. leave on-site or away from forested property). The second section provided attitudinal statements that assessed perceptions on the potential ecological impacts of harvesting woody biomass (e.g. limit the regrowth of forests, degrade wildlife habitat, and result in soil erosion) and respondents' overall level of support of harvesting biomass for bioenergy. All statements were rated using a five-point 
Likert scale ( $1=$ Strongly disagree, $3=$ Neither agree nor disagree, $5=$ Strongly agree). The third section identified price preferences for harvesting using a choice experiment method. The fourth section asked reasons for forest ownership. The final section gathered respondents' demographic information. Most of the reasons for forest ownership (e.g. owning the forests for beauty and scenery, for firewood production, and leave it unmanaged) and options for demographic information were taken directly from the U.S. Forest Service's National Woodland Owner Survey for comparison purposes (U.S. Forest Service, 2012). Variables used to empirically measure the effects of explanatory variables grouped by $\mathrm{L}, \mathrm{LO}$, and $\mathrm{E}$ categories are presented in Table 1.

\section{[INSERT TABLE 1 ABOUT HERE]}

The discrete choice experiment included in the third section of the survey elicited NIPF owners' WTH sensitivity to prices and corresponding revenues. To do so, four timber and four biomass price levels were set based on the average timber and biomass prices predominant in each state at the time of the study. Timber revenue levels per hectare were estimated based on stand composition data from FIA data (Miles, 2012) and timber price by species provided by Timber Mart North (Prentiss \& Carlisle, 2011a, 2011b, 2011c). The four revenue levels per hectare estimated for Michigan were $\$ 850, \$ 1013, \$ 1210$ and $\$ 1408$; in Minnesota, $\$ 889, \$ 1112, \$ 1334$ and \$1556; and in Wisconsin, $\$ 1062, \$ 1334, \$ 1606$ and $\$ 1877$. In terms of woody biomass prices, four woody biomass price offers based on the average bio-stumpage rate for each state. Biomass prices at the time ranged from $\$ 1.5$ to $\$ 2$ per green metric ton (Donald Deckard, pers. comm., Aug. 17, 2011), and on average, there were around 49.40 green tons of woody biomass 
per hectare (Aguilar et al. 2014a) leading to approximate biomass harvest revenues between $\$ 74 / \mathrm{ha}$ and $\$ 98.8 / \mathrm{ha}$. Specific woody biomass revenues per hectare were set at $\$ 0, \$ 49, \$ 98$, and \$149. Combinations of timber and biomass revenue offers, in the form of a timber harvesting profiles were randomly generated using a Bretton-Clark orthogonal design (Bretton-Clark, 1988). Twelve harvesting scenarios were constructed and divided among four survey versions per state. Each scenario consisted of one timber revenue offer and one woody biomass revenue offer. Study participants were given the option to harvest only timber, or not harvest at all. The responses to the hypothetical harvesting scenarios were binary in nature ("Yes" or "No") according to whether respondents chose to accept or reject a stated offer. Except for revenue levels, the final survey instrument was the same for the three states.

A mail-based survey was chosen due to the cost effectiveness. A database was generated by selecting eight counties from each state; the selection was made from a list generated using FIA data and tools in ArcMap to derive only those counties with at least 7 million dry tons of total tree biomass on private lands. Next, landowner data was collected (names, addresses, forest parcel sizes) from the respective county tax assessors or online where parcel maps were available. Eight hectares was used as the minimum ownership size for inclusion in the study since at the time it was considered the minimum ownership size necessary to engage in commercial forest management (Butler and Leatherberry, 2004; Row 1978). The final mailing database consisted of 4,190 landowners. Surveys were mailed from March to April 2012 following Dillman's Tailored Design Method (Dillman, 2000). The first round of surveys with cover letters was mailed one week following the mailing of initial postcards that invited potential 
respondents to participate in the bioenergy study. Thank you and reminder postcards were sent two weeks later followed by a final survey mailing.

\subsection{Econometric analysis}

Econometric analyses were carried out using Stata version 10.0. A dichotomous variable for WTH $(1=$ Yes, $0=$ No) captured NIPF owners' stated choice. Binary logistic regression models of WTH estimated explanatory variable coefficients and corresponding statistical significance using cluster robust standard errors as multiple responses were given per respondent (Hoechle, 2007). Coefficient interpretations was based on estimated odds ratio that examined the ratio of the probability of WTH $(p)$ over the probability of being unwilling-to-harvest (1-p) as a result to changes in explanatory variables (Greene, 2011). Specifically, odds ratios explored the impact of one unit increase in $x_{j}$ (with $\beta_{j}$ as its coefficient) on WTH probabilities.

Two regression models were generated for each state. A full model controlled for all explanatory variables and a reduced model was used to discern the particular effects of timber and biomass revenues on WTH. The reduced model estimated revenue effects on the average NIPF owner. Results from this model were used to calculate cumulative probabilities associated with WTH to harvest timber and biomass at each price level. For these estimates, the variable representing the option offered to sell woody biomass was set to " 1 " and timber and biomass price were set at the different price levels. The cumulative probability was used to estimate the responsiveness of NIPF owners' WTH to changes in revenues from timber and woody biomass harvests. The subtraction of two consecutive cumulative probabilities yielded the marginal probability. 


\title{
5. Results and Discussion
}

\subsection{Descriptive Statistics}

The adjusted response rate, after accounting for non-deliverables, and non-responses was $32 \%$. This rate is comparable to recent NIPF owners surveys in Missouri (34\%) and Mississippi (28.8\%) (Daniel, 2012; Gruchy et al., 2011). At the state level, the highest response rate was from the state of Minnesota (45\%), followed by Wisconsin (32\%) and finally from Michigan (31\%). As with the NWOS, a majority of surveys came from male owners with the average respondent being between 45 and 64 years of age (Table 2). In terms of education level, approximately $40 \%$ of respondents indicated they had at least a bachelor degree, about $10 \%$ higher than respondents from the NWOS Great Lakes States sample. Income distribution in our sample and the NWOS showed similar trends.

\section{[INSERT TABLE 2 ABOUT HERE]}

\begin{abstract}
Regarding land characteristics, a lower percentage of our respondents (22\% from the three states), compared with NWOS respondents, reported a parcel size between 8 and 20 ha. Our sample had a higher percentage of ownerships between 21 and 201 ha. At the average, our surveyed respondents owned 68 ha of forestland and owned their land for about 25 years. An estimated $75 \%$ of respondents indicated that their woodlands had direct access to roads. The percent of owners possessing properties with road access were comparable for the three states: 83\% in Michigan, 76\% in Minnesota and 69\% in Wisconsin. A similar trend was observed for length of ownership that ranged between 24 and 29 years across states.
\end{abstract}


In terms of ownership objectives, enjoying beauty or scenery was ranked as the most important in our survey, which is consistent with results from the NWOS. However, the percentage of NIPF owners who owned woodlands for production of firewood or sawlogs, pulpwood or other timber products was on average higher than the NWOS sample. Regarding bioenergy views, more than half of our respondents indicated they support harvesting woody biomass for energy. Across states, the largest percent of respondents indicating support for woody biomass harvesting were in Minnesota (60\%), followed by Michigan (58\%) and Wisconsin (55\%).

Compared with respondents in Wisconsin, a smaller percent of respondents from Minnesota and Michigan agreed with the statement that "Commercial harvesting of woody biomass is likely to limit the regrowth of forests", "Harvesting woody biomass is likely to degrade wildlife habitat", and "Harvesting woody biomass is likely to result in soil erosion". This suggests that Wisconsin respondents had, on average, greater concerns about the ecological impacts of harvesting woody biomass.

Responses regarding future harvest plans indicated that approximately 19\% of Michigan and Wisconsin respondents did not plan to harvest in the future, compared with 17\% in Minnesota. About $35 \%$ of respondents in the overall sample indicated they did not know their future harvest plans suggesting the potential for those same landowners to harvest in the future. Over $60 \%$ of respondents from Minnesota reported to have a forest management plan written by a professional forester, compared with 29\% in Michigan and 30\% in Wisconsin. 


\subsection{Econometric Analysis}

\subsubsection{External factors: Revenues and Biomass harvest}

The sign and statistical significance of revenues associated with timber and woody biomass prices and the inclusion to remove woody biomass in a harvest offer were similar across all models (Table 3). Figure 1 depicts a chart that illustrates the impacts and significance of external factors on NIPF owners' WTH. Odds ratios of explanatory external variables and bubble sizes representing corresponding $p$-values are provided. Variables capturing timber and woody biomass price levels and the inclusion to remove woody biomass were all statistically significant at a 5\% Type-I error. The odds ratios for timber and woody biomass revenues were highest in Minnesota. A one dollar increase in timber revenues lead to NIPF owners' WTH probabilities to increase around $0.6 \%$ and $1.0 \%$ in Minnesota. Corresponding effects were $0.5 \%$ and $0.6 \%$ in Michigan, and 0.4 and \% $0.8 \%$ in Wisconsin. This finding is consistent with the results of Becker et al., (2010), Binkley (1981), Boyd (1984), Newman and Wear (1993) and Pattanayak et al., (2003) who reported a positive but relatively inelastic response in harvesting behavior to price changes.

\section{[INSERT TABLE 3 ABOUT HERE]}

Our results also indicated a degree of heterogeneity in regard to revenue impacts on NIPF owners' harvest behavior/preferences likely caused by regional differences (Beach, et al., 2005). In this regard Minnesota NIPF owners were relatively more responsive to timber and biomass revenues. Our study suggests after applying the same research methods, there were regional differences in NIPF owners' level of revenue influence on stated WTH. In terms of the inclusion of a woody biomass harvest option, it had a negative impact and its magnitude was the greatest 
in Minnesota followed by Wisconsin and Michigan. Overall the effect of woody biomass

harvesting, holding else constant, reduced the likelihood of accepting an offer to harvest biomass by 44\% (Minnesota), 42\% (Wisconsin) and 28\% (Michigan).

\section{[INSERT FIGURE 1 ABOUT HERE]}

\subsubsection{Land Attributes}

The estimated impact of parcel sizes on NIPF owners' WTH was not statistically significant and no regional differences were detected (Table 3). This result is consistent with those reported by Conway et al. (2000), Joshi and Arano (2009) and Markowski-Lindsay et al. (2012), among others. The accessibility of a forested parcel to a country road or highway did not influence NIPF owners' WTH either in any of the three states. We had expected a positive and significant impact since easier road access may lower harvesting costs and further encourage NIPF owners' to engage in harvesting activities. However, although the parcels of many NIPF owners might have direct road access ( $74 \%$ in the sample) this factor was, on average, not determinant to WTH. There were some discernable regional differences when comparing the impacts of volume of commercial timber on Michigan, Minnesota and Wisconsin NIFO owners' WTH. Variables representing timber volume all had positive signs, but the effect was significant only among Wisconsin NIPF owners. It is possible that this variable, which was used as a proxy for larger scale sawtimber availability, was not significant as WTH is driven by conditions specifics to an owner's forested parcel independent on conditions at a larger geographic scale.

[INSERT FIGURE 2 ABOUT HERE]

\subsubsection{NIPF Owner Attributes}


Evaluation of NIPF owner impacts on WTH benefits from a distinction between respondents from each state. Ownership objectives and attitudinal variables dominated effects associated with NIPF owners' in the Michigan model. The greatest effect on WTH was attributed to owners' supportive attitude toward bioenergy (Figure 3). WTH odds among Michigan NIPF owners who stated support toward biomass harvest for energy were 1.313 times higher of those who did not. The greatest inverse effect on WTH was found to be associated with having no plans to harvest NIPF owners in Michigan who reported this attitude were $70.0 \%$ less willing to harvest, else constant. NIPF owners who owned their land for production of firewood for personal use were on average $29.7 \%$ less likely to harvest than those who did not.

\section{[INSERT FIGURE 3 ABOUT HERE]}

Results from the Minnesota sample showed six variables significantly associated $(p$-value $<$ 0.05 ) with NIPF owners' WTH. The greatest effect on WTH was associated with membership in a forest or environmental organization; the odds of being willing to harvest were 1.173 among group members over the odds of non-members (Figure 4). Involvement in an environmental or

forest organization might enhance educational opportunities for forest owners and could result in a consequent effect on them being more willing to manage their lands for multiple uses.

Minnesota NIPF owners' WTH was affected by absentee ownership, suggesting that landowners residing on or on land adjacent to their woodlands were $75.5 \%$ more willing to harvest, holding all other variables constant. Differences between absentee and onsite owners' harvesting preferences had the same directional effects as the results from Becker et al. (2013) but in the latter were not statistically significant. However, due to their definition for absentee ownership (primary residence are at least 50 miles away from forest ownership) being different findings are 
not directly comparable. The other NIPF owner variables found to have inverse and statistically significant effects on WTH were: agreement to the statement that harvesting woody biomass would likely result in soil erosion, having no plans to harvest regardless of price, owning woodlands to leave it unmanaged and owning woodlands for aesthetic reasons. NIPF owners who explicitly stated that they had no plans to harvest were $59.0 \%$ less willing to harvest, relative to those with plans to do so. Minnesota NIPF owners who agreed to the statement that harvesting woody biomass would result in soil erosion and those who own woodlands for aesthetic reasons were $68.3 \%$ and $19.9 \%$ less willing to harvest their woodlands, ceteris paribus.

\section{[INSERT FIGURE 4 ABOUT HERE]}

Among Wisconsin NIPF owners' WTH results show five landowner descriptors were statistically significant. Similar to findings for Michigan and Minnesota, having no plans to harvest regardless of price negatively influenced WTH, these NIPF owners were $84.9 \%$ less willing to harvest than those with future harvesting plans. Consistent with Michigan's respondents, Wisconsin's NIPF owners' decisions to harvest were positively influenced by their support for bioenergy but negatively influenced by owning woodlands for firewood production. WTH was $95.7 \%$ greater among NIPF owners who indicated support toward harvesting of woody biomass for bioenergy but $19.9 \%$ lower when owning woodlands for firewood production was an important ownership objective. Else constant, NIPF owners who have previously sold timber were $90.0 \%$ more likely to harvest their woodlands for timber and woody biomass. The magnitude of this effect was only second to the biomass support attitude, among those variables positively affecting WTH. Interestingly, among those with future plans to harvest timber, NIPF 
owners who harvested in the past were $54.6 \%$ less likely to harvest their woodlands for timber and woody biomass compared to others who had not harvested, else constant.

Demographic variables, including age, education, annual household income and having children under 18 living at home, did not exhibit statistically significant effects on NIPF owners' WTH in (Figure 4). The insignificant age impacts have been previously found to positively affect WTH timber and woody biomass (Aguilar et al., 2014a). However, our finding is consistent with those from other studies (Binkley, 1981; Bolkesjo and Baardsen, 2002). Older NIPF owners tend to be less likely to harvest as they are more likely to bequest their land to children or others (Butler and Leatherberry, 2004; Joshi and Arano, 2009). Income effects are also consistent with Boyd (1984) and Joshi and Arano (2009). The insignificant effects of income categories may be partly due to that expected timber harvest revenues were not very particularly high at the time of the study, hence household annual income level did not help explain any variability in WTH responses.

\subsubsection{Willingness-to-harvest Probabilities}

NIPF owners' WTH probabilities under different timber and biomass revenue levels are presented in Figure 5. The upward trend in WTH cumulative probabilities is similar across states. For instance, in Michigan harvest probability increased from $25.6 \%$ to $28.5 \%$ when biomass revenue changed from $\$ 49 /$ ha to $\$ 148 /$ ha, when timber revenues constant at $\$ 815 /$ ha. But largest effects on WTH were associated with higher timber revenues as denoted by the vertical distance between curves presented in Figure 5. 
Greater effects of timber revenue on WTH probabilities compared with woody biomass revenues were also discernable by examining the responsiveness to revenue changes. Again, using Michigan as an example, WTH probabilities changed from $25.6 \%$ to $27.0 \%$ (5.4\% increase relative to initial WTH probability) when biomass revenue increased from $\$ 49 /$ ha to $\$ 98 / \mathrm{ha}$ ( $100 \%$ increase in biomass revenue), keeping timber revenues at $\$ 815 /$ ha. This very inelastic response corresponds to a $1 \%$ change in biomass revenue leading to a $0.054 \%$ change in $\mathrm{WTH}$ probability. However, an elasticity of 1.14 in WTH with respect to $1 \%$ change in timber revenues was found when biomass revenue was $\$ 62 / \mathrm{ha}$.

\section{[INSERT FIGURE 5 ABOUT HERE]}

Comparison of NIPF owners' WTH probabilities among the three states for revenues from prevalent timber market revenues (Michigan: \$1013/ha, Minnesota: \$1112/ha, Wisconsin: $\$ 1334 /$ ha) suggests that NIPF owners in Minnesota were 35.6\% more likely to harvest their woodlands compared to their counterparts in Michigan and Wisconsin (32.0\% and 30.1\%) when woody biomass revenue was $\$ 49 / \mathrm{ha}$. Minnesota NIPF owners' WTH probabilities were also found to be more responsive to woody biomass revenue changes, at current timber revenues. For instance woody biomass revenues going from $\$ 0 /$ ha to $\$ 49 /$ ha resulted in estimated WTH probability increases 3.6\% in Minnesota as compared with 1.6\% and 2.6\% in Michigan and Wisconsin, respectively.

The potential availability of woody biomass levels at different prices has been evaluated in several reports such as the Billion Ton Update (U.S. Department of Energy 2011). But the 
evaluations seem to have omitted (a) the interaction of woody biomass such as logging residues and/or thinning with stumpage timber revenues, and (b) landowner conditions affecting potential WTH biomass. Our results point to the major effect that timber revenues have on the social availability of woody biomass. NIPF owners although sensitive to revenues from woody biomass, showed their WTH was mostly influenced by timber revenues. In addition to market prices, NIPF owner inherent characteristics will likely influence the supply of biomass which will be of particular importance in regions where private ownership dominates forestlands as in the case of the U.S. Great Lakes. Across states, revenues had a direct effect on WTH but most of the differences in WTH levels were linked to attitudes and past experiences. Attitudes toward woody biomass harvesting will play a key role in supply from NIPFs. As noted previously, factors such as support for the harvesting and utilization of woody biomass, ownership objectives, plans for harvesting and landowners' harvesting experience will largely determine WTH. Heterogeneous revenue and attitudinal effects across regions increase the complexity of evaluating the social availability of woody biomass supply. Arguably, county-level estimates of woody biomass should not be limited for cost per ton delivered to roadside (e.g. as provided by U.S. Department of Energy 2011) and might need to be revisited after controlling for the aforementioned NIPF owner variables.

\section{Conclusions}

This study found both positive prospects and constraints to the social availability of woody biomass as indicated by the factors affecting landowners' WTH. Results from a survey of Michigan, Minnesota and Wisconsin NIPF owners pointed to similarities and disparities associated with the impacts of social factors on WTH probabilities across regions. External price factors such as timber and woody biomass prices that will affect revenues per ha affected WTH 
but owners were most responsive to timber revenue changes. Among NIPF owners' attributes, their attitudes toward woody biomass harvesting was the most influential on stated WTH, with a positive view directly associated with high WTH levels. The option of including a woody biomass harvest as part of a commercial harvest offered reduced WTH, as did when owners indicated no future plans to harvest their woodlands in the future, else constant.

There were state-level differences found between average responses from NIPF owners in Michigan, Minnesota and Wisconsin. Under prevalent timber market revenues and woody biomass revenues NIPF owners in Minnesota reported the highest WTH level. They were also found to be more responsive to revenue levels changes, although overall marginal responses were relatively inelastic, and more supportive of woody biomass harvesting, else constant. Some variables that significantly affected Minnesota respondents' WTH were found to be insignificant in the other two states. These factors included: residence ownership, membership in an environmental organization, attitudes toward the impacts of woody biomass harvesting on soil erosion, and owning woodlands to enjoy beauty and scenery. Different from average responses in Michigan and Minnesota, Wisconsin NIPF owners showed greater concerns about the environmental and biophysical impacts of harvesting woody biomass, and a lower level of support for woody biomass harvesting.

A combination of logistic binary regression results and probability estimates indicate that the viability of a bioenergy market rests upon flourishing timber markets since it is timber revenues rather than biomass revenues that will likely drive NIPF owners' decision to harvest it. But attitudes matter greatly too. Support toward harvesting biomass for energy was the strongest 
explanatory factor behind stated WTH. Our findings show that the effect of including a biomass harvesting option was negative, else constant, although the magnitude of its effect differed between samples. However, our results show that this effect can be likely offset by positive attitudes regarding the role of bioenergy from biomass in energy portfolios. Heterogeneity in results regarding the influence on woodland ownership objectives such as for the production of

firewood and perceptions about impacts of biomass removals on the land suggest that any efforts toward informing NIPF owners attitudes on the opportunities and challenges associated with woody biomass harvests should be crafted to meet the concerns of local NIPF owners. In this regard, outreach programs designed to encourage more active management and potentially the supply of timber and biomass will likely be more effective if addressing local environmental concerns.

\section{Acknowledgments}

This research was partly funded by the US Department of Agriculture/US Department of Energy Biomass Research and Development Initiative (\#2009-10006-05948) and the US National Institute for Food and Agriculture project number MO-NRSL0893. 


\section{Literature Cited}

Aguilar, F.X., Daniel, M., Cai, Z., 2014a. Family-forest owners' willingness to harvest sawlogs and woody biomass: The effect of price on social availability. Agricultural and Resource Economics Review. 43(2), 1-21.

Aguilar, F.X., Cai, Z., D'Amato, A. 2010. 2014b. Non-industrial private forest landowner's willingness-to-harvest: How higher timber prices can increase woody biomass supply. Biomass and Bioenergy. 72, 202-215.

Aguilar, F.X., Garrett, H.E., 2009. Perspectives of woody biomass for energy: Survey of state foresters, state energy biomass contacts, and National Council of Forestry Association Executives. J. Forest. 107(6), 297-306.

Aguilar, F.X., Mabee, W., 2014. Chapter 1: Wood: A renewable source of energy. In: Aguilar, F.X., (Eds), Wood energy in developed economies: resource management, economics and policy. Routledge, pp. 1-31.

Aguilar, F.X., Saunders, A., 2010. Policy instruments promoting wood-to-energy uses in the continental United States. J. Forest. 108(3), 132-140.

Amacher, G.S., Conway, M.C., Sullivan, J., 2003. Econometric analyses of nonindustrial forest landowners: Is there anything left to study? J. Forest Econ. 9(2), 137-164.

Bartuska, A., 2010. Why is biomass important- the role of the USDA Forest Service in managing and using biomass for energy and other uses. Available online at: http://www.fs.fed.us/research/pdf/biomass_importance.pdf, last accessed: May 2, 2012.

Becker, D.R., Eryilmaz, D., Klapperich, J. J., Kilgore, M.A. 2013. Social availability of residual woody biomass from nonindustrial private woodland owners in Minnesota and Wisconsin. Biomass and Bioenergy. 56, 82-91.

Becker, D.R., Klapperich, J.J., Domke, G.M., Kilgore, M.A., D’Amato, A.W., Current, D.A., Ek, A.R., 2010. 2010 Outlook for Forest Biomass Availability in Minnesota: Physical, Environmental, Economic and Social Availability. Staff Paper Series No. 211, Department of Forest Resources, University of Minnesota.

Becker, D., Skog, K., Hellman, A., Halvorsen, K., Mace, T. 2009. An outlook for sustainable forest bioenergy production in the Lake States. Energ Policy., 37(12), 5687-5693.

Beach, R.H., Pattanayak, S.K., Yang, J.C., Murray, B.C., Abt, R.C. 2005. Econometric studies of non-industrial private forest management: a review and synthesis. Forest Policy Econ., 7(3), 261-281.

Binkley, C.S., 1981. Timber supply from private nonindustrial forests. Bulletin No. 92, New Haven, CT: School of Forestry and Environmental Studies, Yale University. 
Bolkesjø, T.F., Baardsen, S. 2002. Roundwood supply in Norway: micro-level analysis of selfemployed forest owners. Forest Policy Econ., 4(1), 55-64.

Boyd, R.G., 1984. Government support of non-industrial production: The case of private forests. Southern Economic Journal. 51, 89-107.

Bretton-Clark, 1988. Conjoint Designer. Bretton-Clark Co, New York.

Butler, B.J., 2007. Private Forest Owners: Past, Present and Future. Society of American Foresters National Convention. Available online at: http://www.auburn.edu/academic/forestry_wildlife/forest_policy_ctr/SAF/day1 bbutler.pdf, last accessed: June $14^{\text {th }}, 2012$.

Butler, B.J., 2008. Family Forest Owners of the United States, 2006. Gen. Tech. Rep. NRS-27. United States Department of Agriculture, Forest Service, Northern Research Station.

Butler, B.J., Leatherberry, E.C., 2004. America's family forest owners. J. Forest., 102(7), 4-9.

Butler B.J., Ma, Z., Kittredge, D.B., Catanzaro, P., 2010. Social versus biophysical availability of wood in the northern United States. Northern J. Appl. For., 27(4), 151-159.

Conway, C., Chapman, S., Amacher, G.S., Sulliavan, J., 2000. Differences in non-industrial landowner behavior between hardwood and pine regions of Virginia: implications for timber supply. SOFAC Report No. 19.

Daniel, M., 2012. Social Availability of Woody Biomass for Renewable Energy: Missouri NonIndustrial Private Forest Landowners' Perspective. M.Sc. thesis, Univ. of Missouri, Columbia, Missouri, U.S.A.

Dillman, D., 2000. Mail and Internet Surveys: The tailored design method. 2nd ed. John Wiley Co., New York.

Energy Information Administration. 2014. Increase in wood as main source of household heating most notable in the Northeast. Available online at: http://www.eia.gov/todayinenergy/detail.cfm?id=15431, last accessed: May 2, 2012.

Goerndt, M.E., Aguilar, F.X., Miles, P., Shifley, S., Song, N., Stelzer, H., 2012. Regional assessment of woody biomass physical availability as an energy feedstock for combined combustion in the US Northern Region. J. Forest., 110(3), 138-148.

Greene, W.H. 2011. Econometric Analyses. 7th ed. Pearson Education Inc. New Jersey, U.S. $1232 p$.

Gregory, S.A., Conway, M.C., Sullivan, J., 2003. Econometric analyses of nonindustrial forest landowners: is there anything left to study?. J. Forest Econ., 9(2), 137-164. 
Gruchy, S.R., Grebner, D.L., Munn, I.A., Joshi, O., Hussain, A., 2011. An assessment of nonindustrial private forest landowner willingness to harvest woody biomass in support of bioenergy production in Mississippi: A contingent rating approach. Forest Policy Econ., 15, 140-145.

Hall, D.O., 1997. Biomass in industrialized countries - a view of the future. Forest Ecol. Manag., 91(1), 17-45.

Hoechle, D., 2007. Robust standard errors for panel regressions with cross-sectional dependence. Stata Journal, 7(3), 281.

Hubbard, W., Biles, L., Mayfield, C., Ashton, S., 2007. Sustainable Forestry for Bioenergy and Bio-based Products: Trainers Curriculum Notebook. Athens, GA: Southern Forest Research Partnership, Inc.

Joshi S., Arano K.G., 2009. Determinants of private forest management decisions: a study on West Virginia NIPF landowners. Forest Policy Econ., 11(2), 118-25.

Joshi, O., Grebner, D.L., Hussain, A., Grado, S.C., 2013. Landowner knowledge and willingness to supply woody biomass for wood-based bioenergy: Sample selection approach. J. Forest Econ., 19(2), 97-109.

Joshi, O., Mehmood, S.R., 2011. Factors affecting nonindustrial private forest landowners' willingness to supply woody biomass for bioenergy. Biomass and Bioenergy. 35(1), 186-192.

Kurtz, W.B., Lewis, B.J., 1981. Decision-making framework for nonindustrial private forest owners: An Application in the Missouri Ozarks. J. Forest., 79(5), 285-288.

Markowski-Lindsay, M., Stevens, T., Kittredge, D.B., Butler, B.J., Catanzaro, P., Damery, D., 2012. Family forest owner preferences for biomass harvesting in Massachusetts. For Policy Econ, 14(1), 127-135.

Miles, P.D., 2012. Forest Inventory EVALIDator web-application version 1.5.1.2 beta. Available online at: www.fiatools.fs.fed.us/Evalidator4/tmattribute.jsp; last accessed November 14, 2012.

Newman, D., Wear, D., 1993. Production economics of private forestry: a comparison of industrial and non-industrial forest owners. Am. J. Agr. Econ., 75, 674- 684.

Pattanayak, S.K., Abt, K.L., Holmes, T.P. 2003. Timber and amenities on nonindustrial private forest land. In Forests in a market economy. Springer Netherlands, pp. 243-258.

Prentiss \& Carlisle, 2011a. Timber Mart North Price Report. Michigan Edition 17(1), 7p.

Prentiss \& Carlisle, 2011b. Timber Mart North Price Report. Minnesota Edition 17(1), 6p. 
Prentiss \& Carlisle, 2011c. Timber Mart North Price Report. Wisconsin Edition 17(1), 7p.

Prestemon, J., Wear, D., 2000. Linking harvest choices to timber supply. Forest Sci., 46 (3), $377-389$.

Public Law 110-140. 2007. Energy Independence and Security Act of 2007. Available online at: http://www.gpo.gov/fdsys/pkg/BILLS-110hr6enr/pdf/BILLS-110hr6enr.pdf, last accessed: October 24, 2012.

Row, C., 1978. Economies of tract size in timber growing. J. Forest., 76(9), 576-582.

Saunders, A., Aguilar, F.X., Dwyer, J.P., Stelzer, H., 2012. Cost structure of integrated harvesting for woody biomass and solid hardwood products in Southeastern Missouri. J. Forest., 110(1), 7-15.

Smith, W.B, Miles, P.D., Perry, C.H., Pugh, S.A., 2009. Forest Resources of the United States, 2007.Gen. Tech. Rep. WO-78.United States Department of Agriculture, Forest Service, Washington Office.

Tonisson, T., 2012. Understanding the NIPF Landowners Attitudes and Knowledge about Forest Management in Michigan. M.Sc. thesis, Swedish University of Agricultural Sciences, Alnarp, Sweden.

U.S. Department of Agriculture, Forest Service, 2012. National Woodland Owner Survey. Available online at: http://www.fia.fs.fed.us/nwos/; last accessed: November 14, 2012.

U.S. Department of Agriculture, Forest Service, 2008. Woody biomass utilization. Available online at: http://www.fs.fed.us/woodybiomass/whatis.shtml, last accessed: November 14, 2012.

U.S. Department of Energy. 2011. U.S. Billion-Ton update: biomass supply for a bioenergy and bioproducts industry. R.D. Perlack and B.J. Stokes (Leads), ORNL/TM-2011/224. Oak Ridge National Laboratory, Oak Ridge, TN. 227p.

U.S. Department of Energy. 2010. USDA awards $\$ 4.2$ million in woody biomass utilization projects. Available online at:

http://www1.eere.energy.gov/cleancities/news_detail.html?news_id=16142, last accessed: November 11, 2014.

U.S. Environmental Protection Agency (EPA), 2010. Renewable Fuel Standard (RFS). Available online at: http://www.epa.gov/otaq/fuels/renewablefuels/index.htm, last accessed: June 15, 2012.

Vokoun, M., Amacher, G.S., Wear, D.N., 2005. Scale of harvesting by non-industrial private forest landowners. J. Forest Econ., 11(4), 223- 244. 
Young, R.A., Reichenbach, M.R., 1987. Factors influencing the timber harvest intentions of nonindustrial private forest owners. Forest Sci., 33(2), 381-393. 


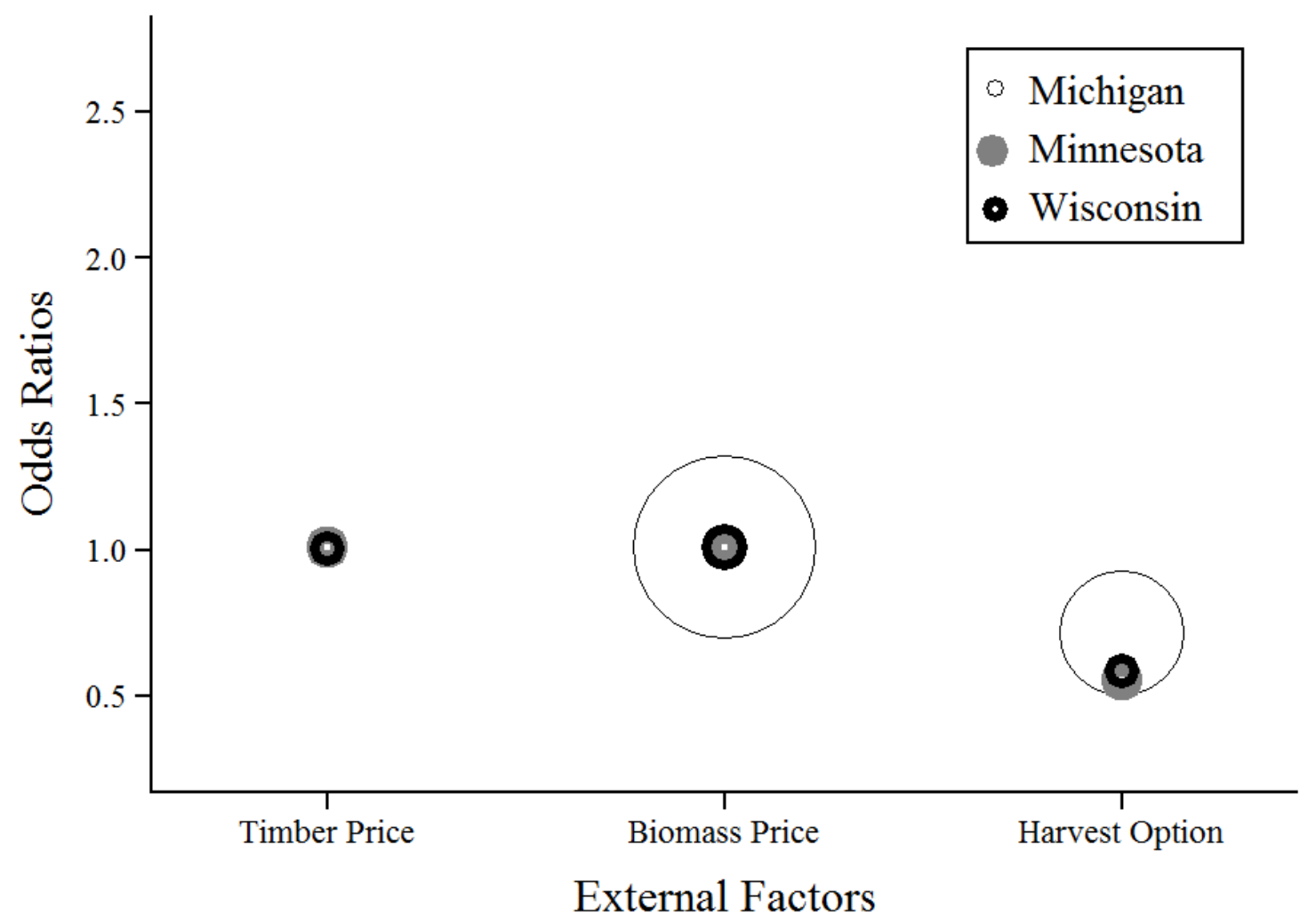

Figure 1. Odds ratios between external factors and NIPF owners' WTH. Centroids in bubbles correspond to odds ratios and size to corresponding $p$-values. 


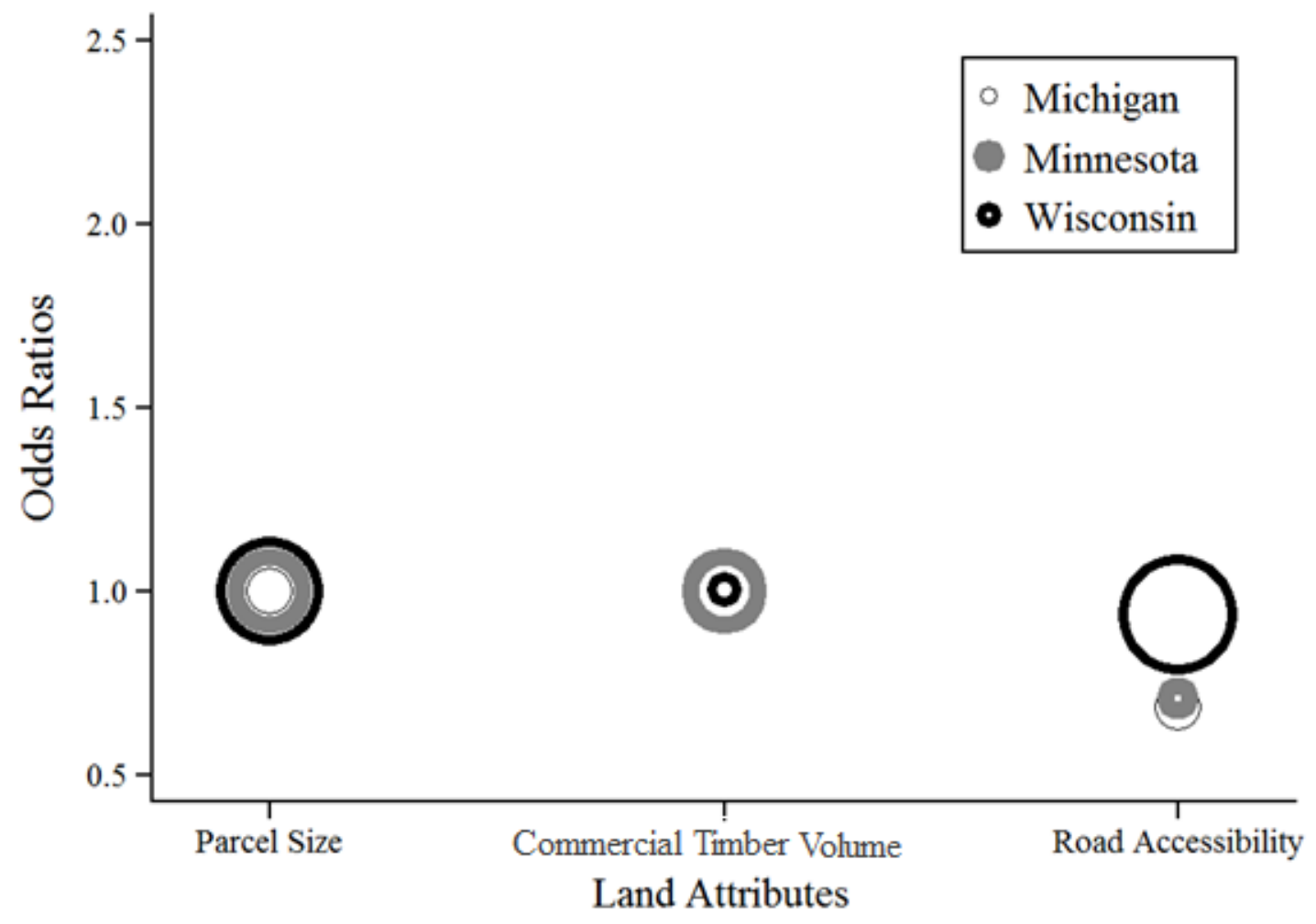

Figure 2. Odd ratios between elicited land attributes on NIPF owners' WTH. Centroids in bubbles correspond to odds ratios and size to corresponding $p$-values. 


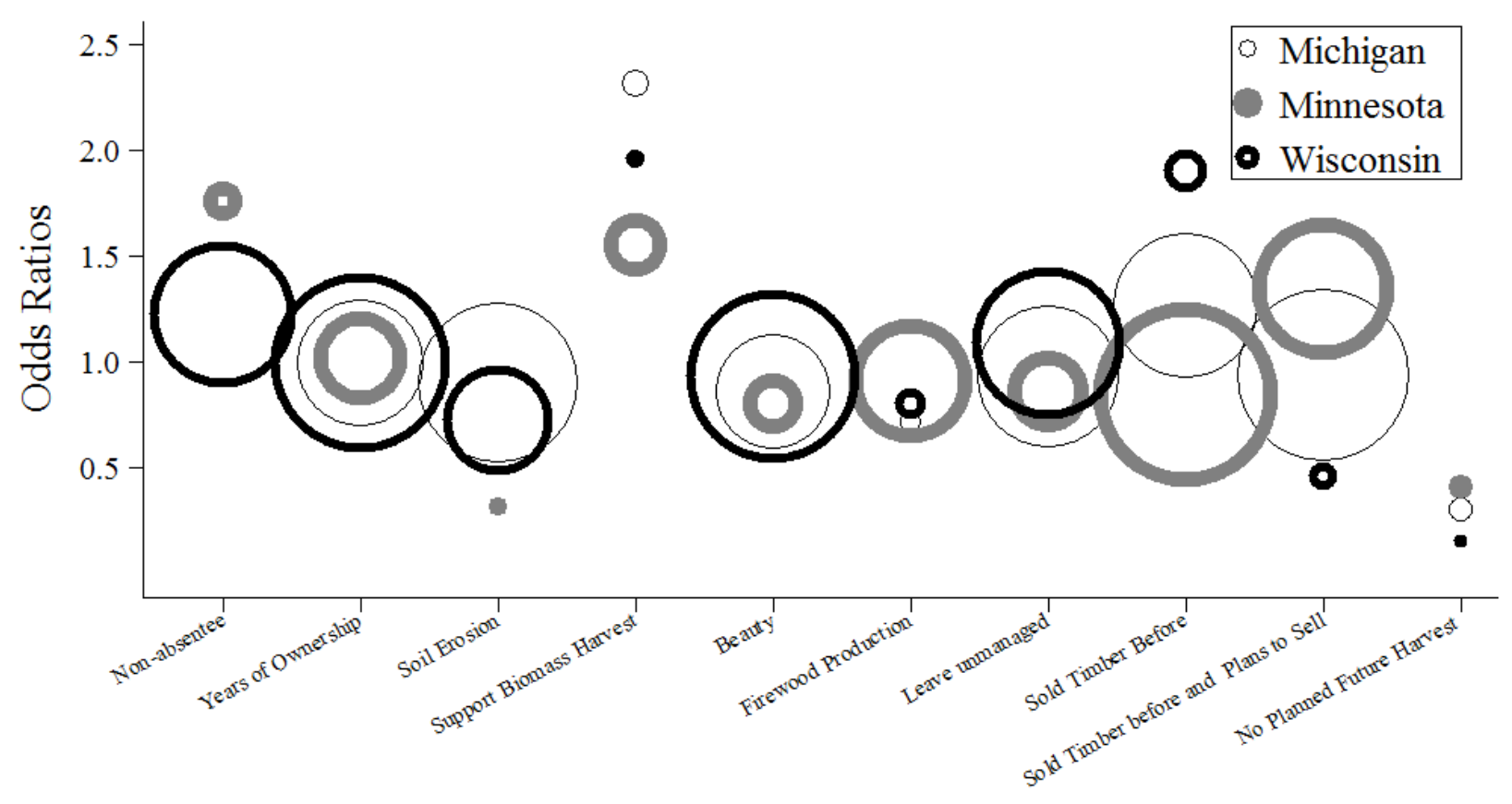

NIPF Owner Attributes - Non-Demographics

Figure 3. Odd ratios between NIPF owner attributes (excluding demographics and program enrollment status) and NIPF owners' WTH. Centroids in bubbles correspond to odds ratios and size to corresponding $p$-values. 


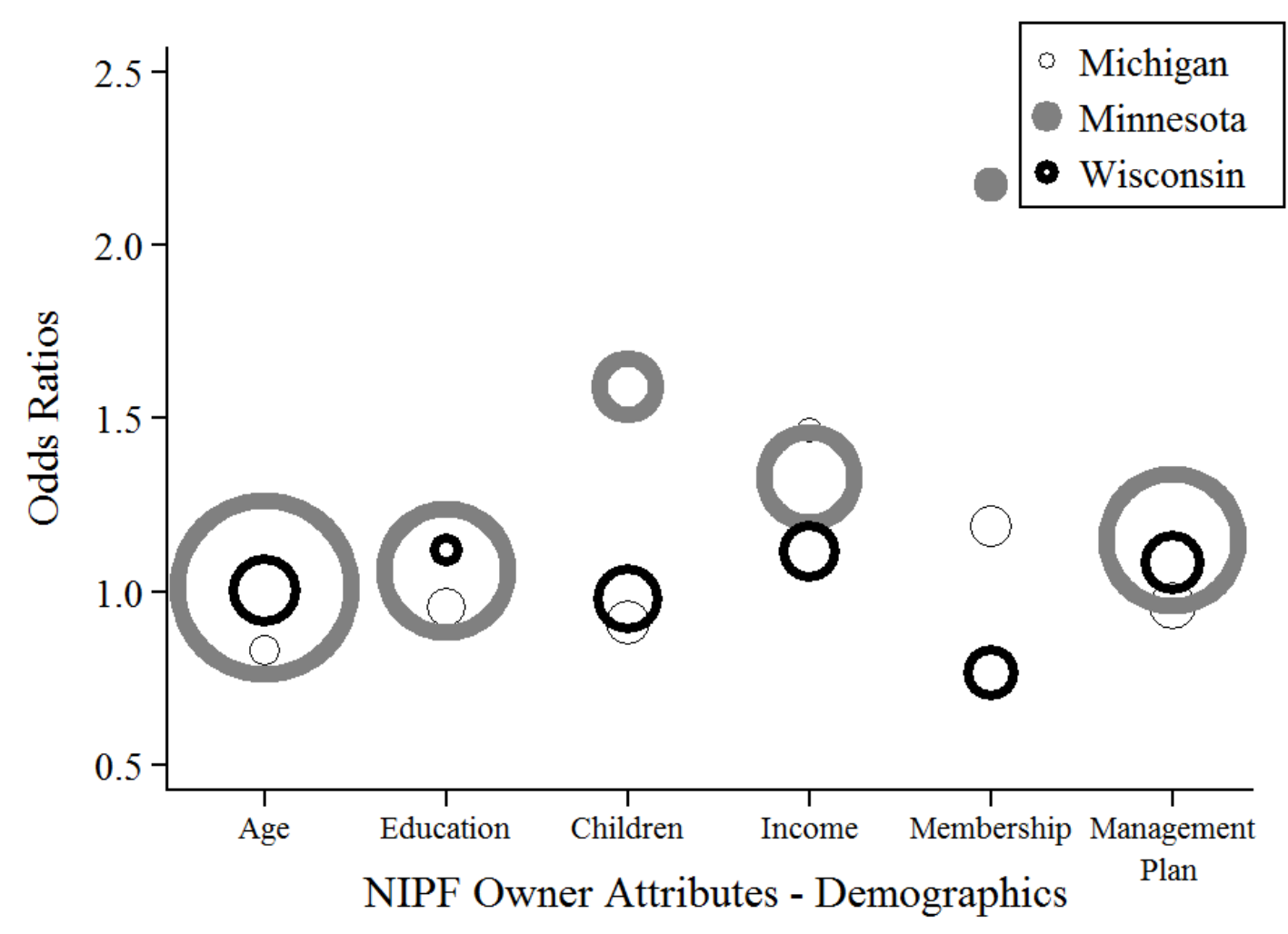

Figure 4. Odds ratios between NIPF owner attributes (demographics and program enrollment status) on NIPF owners' WTH. Centroids in bubbles correspond to odds ratios and size to corresponding $p$-values. 

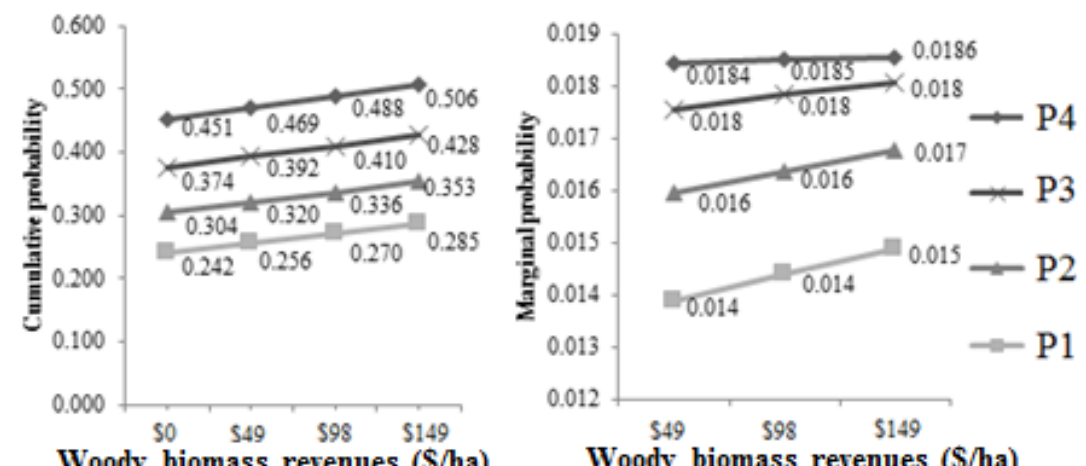

Michigan
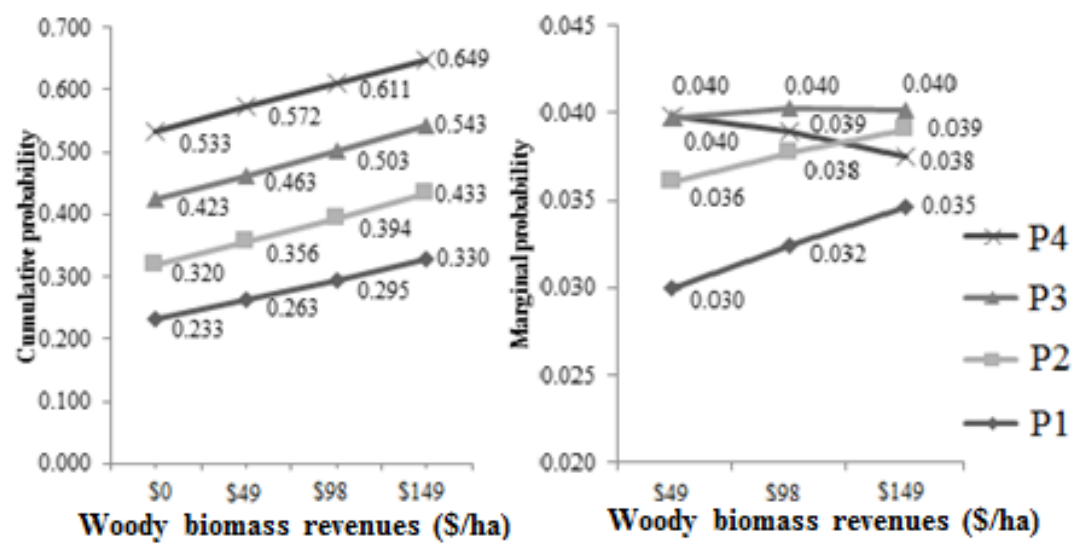

Minnesota
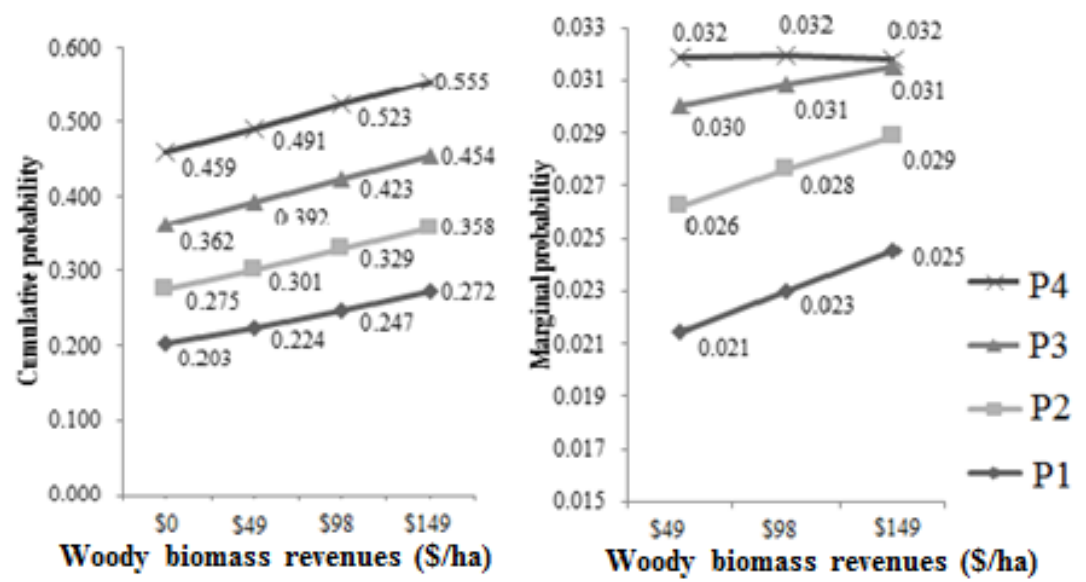

\section{Wisconsin}

Figure 5. Predicted (cumulative) and marginal probabilities associated with landowners' WTH their woodlands in Michigan, Minnesota, and Wisconsin. Timber revenues: Michigan: P1 $=\$ 815 /$ ha, P2=\$1,013/ha, P3=\$1,210/ha, P4=\$1,408/ha; Minnesota: P1=\$889/ha, $\mathrm{P} 2=\$ 1,112 / \mathrm{ha}, \mathrm{P} 3=\$ 1,334 / \mathrm{ha}, \mathrm{P} 4=\$ 1,556 / \mathrm{ha}$; Wisconsin: $\mathrm{P} 1=1,062 / \mathrm{ha}, \mathrm{P} 2=\$ 1,334 / \mathrm{ha}$, $\mathrm{P} 3=\$ 1,606 / \mathrm{ha}, \mathrm{P} 4=\$ 1,877 / \mathrm{ha}$. Marginal probabilities are associated with $\$ 49.4 /$ ha changes in woody biomass revenue offers at each timber price level. All predicted probability estimates were significant at a Type-I error level of 0.001 . 
Table 1. List and description of explanatory variables used in the examination of social availability of woody biomass for bioenergy among NIPF owners of Michigan, Minnesota and Wisconsin.

\section{Explanatory Variable \\ Land Attributes \\ 1. Parcel size \\ 2. Commercial timber volume}

3. Road accessibility

\section{NIPF Owner Attributes}

4. Non-absentee

5. Years of ownership

6. Bioenergy views

Soil erosion

Support biomass harvest

7. Reasons for owning land

Beauty

Firewood production

Leave unmanaged

8. Sold Timber before

9. Sold timber before and plans to sell

10. No planned future harvest

11. Demographic information

Age

Education

Children

Income

13. Membership

14. Management plan

\section{External Factors}

15. Timber revenue

16. Biomass revenue

17. Inclusion of woody biomass harvest option

\section{Description}

Number of woodland hectares owned.

Continuous variable.

In cubic meters, by county.

Continuous variable. Estimates were divided by 100,000 to

downscale figures.

Whether woodlands have direct access to county road or highway Binary variable (1= "Yes", $0=$ "No")

Whether the landowner resides on his/her woodland.

Binary variable ("Yes/ some of it is" $=1$, "No" $=0$ )

Total number of years NIPF owner has owned his/her woodland.

Continuous variable representing land tenure.

Harvesting woody biomass is likely to result in soil erosion.

Binary variable ("Agree" $=1$ and "Disagree" $=0$ )

I support harvesting woody biomass for energy Binary variable

("Agree" $=1$ and "Disagree" $=0$ )

Likert rating scale ( $1=$ Not important to $5=$ extremely important)

was used to measure importance rating of each statement

To enjoy beauty or scenery.

For production of firewood for personal use.

To leave land unmanaged and let nature take its course.

Have sold timber since ownership of woodlands.

Binary variable ("Yes" $=1, " \mathrm{No} "=0$ )

Binary variable ("Yes"=1, "No"=0)

No plans to harvest timber or biomass regardless of price

Binary variable ("Agree"=1, "Disagree"=0)

- Ordinal categories: $1=$ "Under 25 years", $2=$ " 25 to 34 years", $3=$

" 35 to 44 years", $4=$ " 45 to 54 years", $5=$ "55 to 64 years", $6=$ "65

to 74 years" and $7=$ " 75 years or older"

- Categorical: $1=$ "Less than $12^{\text {th }}$ grade", $2=$ "High school graduate or GED", 3= "Some college", 4= "Associate or technical degree",

$5=$ "Bachelor's degree", $6=$ "Graduate degree"

Children under 18 years of age live in the household

Binary variable ("Yes" $=1$, "No" $=0$ )

Annual household income range in dollars per year.

Binary variable (Income $\geq \$ 50,000=1$, Income $\leq \$ 50,000=0$ )

Membership in a forest landowner group or environmental

organization.

Binary variable ("Yes"=1, "No"=0)

Has a professionally written forest management plan.

Binary variable ("Yes"=1, "No"=0)

Continuous variable, in $\$$ hectare

Continuous variable, in $\$$ hectare

Binary variable Both timber and biomass offers proposed $=1$, only timber offer proposed $=0$ ) 
Table 2. Selected characteristics of study sample and the 2002-2006 National Woodland Owner Survey.

\begin{tabular}{|c|c|c|c|c|c|c|}
\hline & \multicolumn{2}{|c|}{ Michigan } & \multicolumn{2}{|c|}{ Minnesota } & \multicolumn{2}{|c|}{ Wisconsin } \\
\hline & $\begin{array}{c}\text { Study } \\
(\mathrm{n}=293)\end{array}$ & $\begin{array}{c}\text { NWOS } \\
(2002-2006) \\
(n=126,000) \\
\end{array}$ & $\begin{array}{c}\text { Study } \\
(\mathrm{n}=592)\end{array}$ & $\begin{array}{c}\text { NWOS }(2002- \\
2006) \\
(n=73,000) \\
\end{array}$ & $\begin{array}{c}\text { Study } \\
(\mathrm{n}=527)\end{array}$ & $\begin{array}{c}\text { NWOS } \\
(2002-2006) \\
(n=129,000) \\
\end{array}$ \\
\hline \multicolumn{7}{|c|}{ NIPF Owner Attributes - Demographics } \\
\hline \multicolumn{7}{|l|}{ Gender (\%) } \\
\hline Male & 79.52 & 78.57 & 87.33 & 79.45 & 82.16 & 81.40 \\
\hline Female & 18.77 & 11.11 & 11.32 & 12.33 & 16.32 & 8.53 \\
\hline No answer/Others & 1.71 & 10.32 & 1.35 & 8.22 & 1.52 & 10.08 \\
\hline \multicolumn{7}{|l|}{ Age $(\%)$} \\
\hline$<55$ & 23.21 & 32.12 & 27.53 & 40.00 & 33.59 & 42.42 \\
\hline $55-64$ & 31.06 & 28.47 & 35.47 & 27.50 & 35.29 & 23.48 \\
\hline $65-74$ & 27.99 & 21.90 & 22.47 & 18.75 & 18.79 & 21.21 \\
\hline$>75$ & 16.04 & 13.87 & 13.01 & 8.75 & 10.63 & 9.85 \\
\hline No Answer & 1.71 & 3.65 & 1.52 & 5.00 & 1.71 & 3.03 \\
\hline \multicolumn{7}{|l|}{ Education (\%) } \\
\hline 12th grade or lower & 3.41 & 7.09 & 1.52 & 5.41 & 1.33 & 6.98 \\
\hline High school & 23.55 & 26.77 & 17.23 & 29.73 & 24.10 & 31.01 \\
\hline Some college & 19.80 & 22.05 & 16.89 & 14.86 & 16.51 & 13.95 \\
\hline Associate degree & 8.19 & 11.02 & 19.93 & 14.86 & 16.89 & 13.95 \\
\hline Bachelor degree & 23.21 & 15.75 & 26.86 & 16.22 & 22.58 & 17.83 \\
\hline Graduate degree & 19.80 & 12.60 & 16.55 & 13.51 & 17.08 & 12.40 \\
\hline No Answer & 2.05 & 4.72 & 1.01 & 5.41 & 1.52 & 3.88 \\
\hline \multicolumn{7}{|l|}{ Income $(\%)$} \\
\hline$<\$ 25,000$ & 11.60 & 12.50 & 5.07 & $11.25 \%$ & 8.54 & 9.16 \\
\hline$\$ 25,000$ to $\$ 49,999$ & 23.89 & 27.94 & 21.45 & $23.75 \%$ & 23.53 & 26.72 \\
\hline$\$ 50,000$ to $\$ 99,999$ & 34.13 & 30.15 & 40.37 & $33.75 \%$ & 33.21 & 32.06 \\
\hline$\$ 100,000$ to $\$ 199,999$ & 12.63 & 11.03 & 20.78 & $11.25 \%$ & 18.22 & 12.98 \\
\hline$\$ 200,000+$ & 6.14 & 3.68 & 5.07 & $5.00 \%$ & 6.45 & 3.82 \\
\hline No Answer & 11.60 & 14.71 & 7.26 & $15.00 \%$ & 10.06 & 15.27 \\
\hline \multicolumn{7}{|c|}{ NIPF Owner Attributes - Non-demographics } \\
\hline \multicolumn{7}{|c|}{ Residential (\%) } \\
\hline YES & 47.10 & 54.40 & 57.43 & 63.01 & 48.96 & 54.26 \\
\hline $\mathrm{NO}$ & 33.45 & 39.20 & 24.66 & 31.51 & 34.54 & 39.53 \\
\hline \multicolumn{7}{|l|}{ No answer/ some parcels far from } \\
\hline primary residence & 19.45 & 6.40 & 17.57 & 6.85 & 15.94 & 6.20 \\
\hline \multicolumn{7}{|l|}{ Reasons for owning land $(\%)$} \\
\hline Beauty & 67.92 & 72.22 & 73.65 & 71.79 & 70.59 & 62.33 \\
\hline Firewood Production & 34.13 & 17.46 & 24.49 & 17.95 & 36.24 & 20.55 \\
\hline \multicolumn{7}{|l|}{$\begin{array}{l}\text { Attitudes to biomass harvest and } \\
\text { biomass energy }(\%)\end{array}$} \\
\hline Soil Erosion & 28.46 & N/A & 24.01 & N/A & 30.82 & N/A \\
\hline Support Biomass Harvest & 58.31 & N/A & 59.71 & N/A & 55.19 & N/A \\
\hline \multicolumn{7}{|l|}{ Sold Timber Before (\%) } \\
\hline YES & 55.97 & 45.24 & 59.29 & 35.62 & 52.75 & 47.73 \\
\hline NO & 44.03 & 50.00 & 40.20 & 60.27 & 46.30 & 45.45 \\
\hline \multicolumn{7}{|l|}{ Land Attributes } \\
\hline \multicolumn{7}{|l|}{ Parcel Size $(\%)$} \\
\hline $8-20$ hectare & 40.62 & 64.80 & 23.82 & 52.05 & 38.90 & 54.69 \\
\hline 21-40 hectare & 26.62 & 21.60 & 31.25 & 28.77 & 31.50 & 26.56 \\
\hline 41-202 hectare & 24.57 & 13.60 & 40.37 & 17.81 & 25.24 & 18.75 \\
\hline 203-404 hectare & 2.73 & 0.00 & 1.35 & 0.00 & 0.57 & 0.00 \\
\hline 405-2023 hectare & 2.73 & 0.00 & 0.34 & 1.37 & 0.57 & 0.00 \\
\hline $2024+$ hectare & 2.73 & 0.00 & 1.69 & 0.00 & 1.33 & 0.00 \\
\hline No Answer & 0.00 & 4.76 & 0.51 & 4.11 & 0.95 & 6.82 \\
\hline
\end{tabular}


Table 3. Logistic regression results for landowners' willingness-to-harvest (WTH)

\begin{tabular}{|c|c|c|c|c|c|c|c|c|c|}
\hline & \multicolumn{4}{|c|}{ Michigan } & \multicolumn{2}{|c|}{ Minnesota } & \multirow[b]{2}{*}{$\beta$} & \multicolumn{2}{|c|}{ Wisconsin } \\
\hline & $\beta$ & OR & $P$-value & $\beta$ & OR & $P$-Value & & OR & $P$-Value \\
\hline \multicolumn{10}{|l|}{ External Factors } \\
\hline Timber revenue & 0.005 & 1.005 & $<0.001$ & 0.006 & 1.006 & $<0.001$ & 0.004 & 1.004 & $<0.001$ \\
\hline Biomass revenue & 0.006 & 1.006 & 0.057 & 0.010 & 1.010 & 0.001 & 0.008 & 1.008 & 0.002 \\
\hline $\begin{array}{l}\text { Option offered to sell } \\
\text { woody biomass }\end{array}$ & -0.334 & 0.716 & 0.026 & -0.585 & 0.557 & $<0.001$ & -0.538 & 0.584 & $<0.001$ \\
\hline \multicolumn{10}{|l|}{ Land Attributes } \\
\hline Acres & -0.001 & 0.999 & 0.399 & $<0.001$ & 1.000 & 0.675 & $<0.001$ & 1.000 & 0.622 \\
\hline $\begin{array}{l}\text { Volume of commercial } \\
\text { timber }\end{array}$ & $<0.001$ & 1.000 & 0.143 & $<0.001$ & 1.000 & 0.695 & 0.001 & 1.001 & 0.048 \\
\hline $\begin{array}{l}\text { County road/highway } \\
\text { accessibility }\end{array}$ & -0.382 & 0.682 & 0.423 & -0.347 & 0.707 & 0.104 & -0.067 & 0.936 & 0.771 \\
\hline \multicolumn{10}{|l|}{ Owner Attributes } \\
\hline Residence on woodland & 0.208 & 1.231 & 0.606 & 0.562 & 1.755 & 0.014 & 0.202 & 1.224 & 0.373 \\
\hline Total years of ownership & -0.006 & 0.995 & 0.486 & 0.012 & 1.012 & 0.123 & -0.006 & 0.994 & 0.566 \\
\hline Soil erosion & -0.107 & 0.899 & 0.797 & -1.148 & 0.317 & $<0.001$ & -0.326 & 0.722 & 0.198 \\
\hline $\begin{array}{l}\text { Support woody biomass } \\
\text { harvesting }\end{array}$ & 0.838 & 2.313 & 0.021 & 0.439 & 1.552 & 0.048 & 0.671 & 1.957 & 0.003 \\
\hline Beauty & -0.150 & 0.860 & 0.408 & -0.222 & 0.801 & 0.046 & -0.075 & 0.928 & 0.537 \\
\hline Firewood production & -0.338 & 0.713 & 0.014 & -0.095 & 0.910 & 0.237 & -0.222 & 0.801 & 0.010 \\
\hline Leave un-managed & -0.071 & 0.932 & 0.621 & -0.151 & 0.860 & 0.091 & 0.084 & 1.088 & 0.401 \\
\hline Have sold timber before & 0.235 & 1.265 & 0.650 & -0.171 & 0.843 & 0.544 & 0.642 & 1.900 & 0.027 \\
\hline $\begin{array}{l}\text { Have sold timber in the } \\
\text { past and plans to sell } \\
\text { timber }\end{array}$ & -0.063 & 0.939 & 0.905 & 0.294 & 1.342 & 0.311 & -0.789 & 0.454 & 0.009 \\
\hline No harvest in the future & -1.202 & 0.300 & 0.019 & -0.892 & 0.410 & 0.003 & -1.888 & 0.151 & $<0.001$ \\
\hline $\begin{array}{l}\text { Forest/environmental } \\
\text { organization membership }\end{array}$ & 0.171 & 1.187 & 0.772 & 0.776 & 2.173 & 0.011 & -0.266 & 0.766 & 0.547 \\
\hline Management plan & -0.042 & 0.958 & 0.925 & 0.139 & 1.149 & 0.530 & 0.079 & 1.082 & 0.735 \\
\hline \multicolumn{10}{|l|}{ Demographics } \\
\hline Age & -0.185 & 0.831 & 0.371 & 0.012 & 1.012 & 0.913 & 0.001 & 1.001 & 0.993 \\
\hline Education & -0.049 & 0.952 & 0.681 & 0.057 & 1.058 & 0.459 & 0.110 & 1.117 & 0.170 \\
\hline $\begin{array}{l}\text { Children under } 18 \text { years } \\
\text { of age live in the } \\
\text { household }\end{array}$ & -0.097 & 0.908 & 0.876 & 0.464 & 1.590 & 0.105 & -0.024 & 0.977 & 0.936 \\
\hline Income $(\geq \$ 50,000 /$ year $)$ & 0.382 & 1.466 & 0.292 & 0.284 & 1.329 & 0.253 & 0.107 & 1.113 & 0.679 \\
\hline Constant & -0.73 & & 0.663 & -2.768 & & 0.004 & -4.795 & & 0.001 \\
\hline
\end{tabular}

